\title{
"I dare do all...": The saga of Dr. Tillson Lever Harrison
}

A serial bigamist, front-line physician in 7 wars, and humanitarian revered in China, Canada's own Dr. Tillson Lever Harrison is a study in contradictions.

Although he was the veteran of 8 armies on 5 continents, Harrison is best known in China for his work in 1946 , when he charged into a politicoeconomic maelstrom engendered by decades of war. He worked untiringly at nominal pay for the United Nations Relief and Reconstruction Administration, which was tasked with one of the more onerous missions in modern history: saving millions of lives in China.

Harrison was considered the second Norman Bethune in China. Unlike Bethune, however, his daughter believed that his life was the model for the Hollywood blockbuster series centred on the mythical Indiana Jones.

Who was this man who attained such a special place in the hearts of the Chinese, yet remains virtually unknown in the country of his birth?

Harrison was born into a prominent Tillsonburg, Ont., family in I88I. A scamp in his youth, he was shipwrecked in a swamp, locked his doting grandmother in her bedroom and was the butt of much mirth when his attempt to "ride the rails" to Cuba hit the local scandal sheets. At I4, he ran off to join the 22nd Oxford Rifles militia, and later, in Igor, he served with the Americans in the Philippines, until his wealthy grandfather intervened. E.D. Tillson, the founder of what became Quaker Oats, finagled an Act of Congress to buy his grandson out of US service. Had Harrison stayed, he might have succumbed to the Asiatic cholera, which subsequently killed several of his chums.
After returning to Tillsonburg, Harrison learned that E.D. had died, leaving a considerable sum for his grandson's education. So there was Harrison: rich, handsome, well-mannered and educated, but above all, adventurous. He used these advantages to become a modern-day medical knight-errant, roaming the world in search of conflicts and causes. Over the years he became multilingual (French, Spanish, Turkish, Arabic and Chinese), a superb writer, raconteur, Don Juan and opportunist, who always sought out the powerful and famous.

On the flip side, Harrison was a serial bigamist with 4 wives, since, in his time, intimacy with women of quality was only possible though marriage. His first venture into matrimony was in 1905, when he wed Sybil Wilkin. After his graduation from the University of Toronto Medical School in I907, the couple settled in Lac Ste. Anne, Alta., where Harrison treated the local Cree residents. His daughter Rosalind was born in I9o9 and the family decamped to Oregon. Although he didn't treat his female partners particularly well, as a doctor he would bring improved medical care to women around the world. In a July IgI2 JAMA article, "Cesarian [sic] Section under Difficulties," he described the delivery of a healthy child to an epileptic woman in a filthy mountain shack.

In I9I3 he left to do postgraduate work in obstetrics and gynecology in London, England, but when World War I erupted, he joined the Belgian Tirailleurs and the French Foreign Legion. Soon, he met and married (without divorcing Edna), Smyrna-born Eva Zambounis. The couple settled in El Paso Texas in I9I5, and Harrison volunteered as medical jefe to General Carranza, but was captured by Villistas (ac-

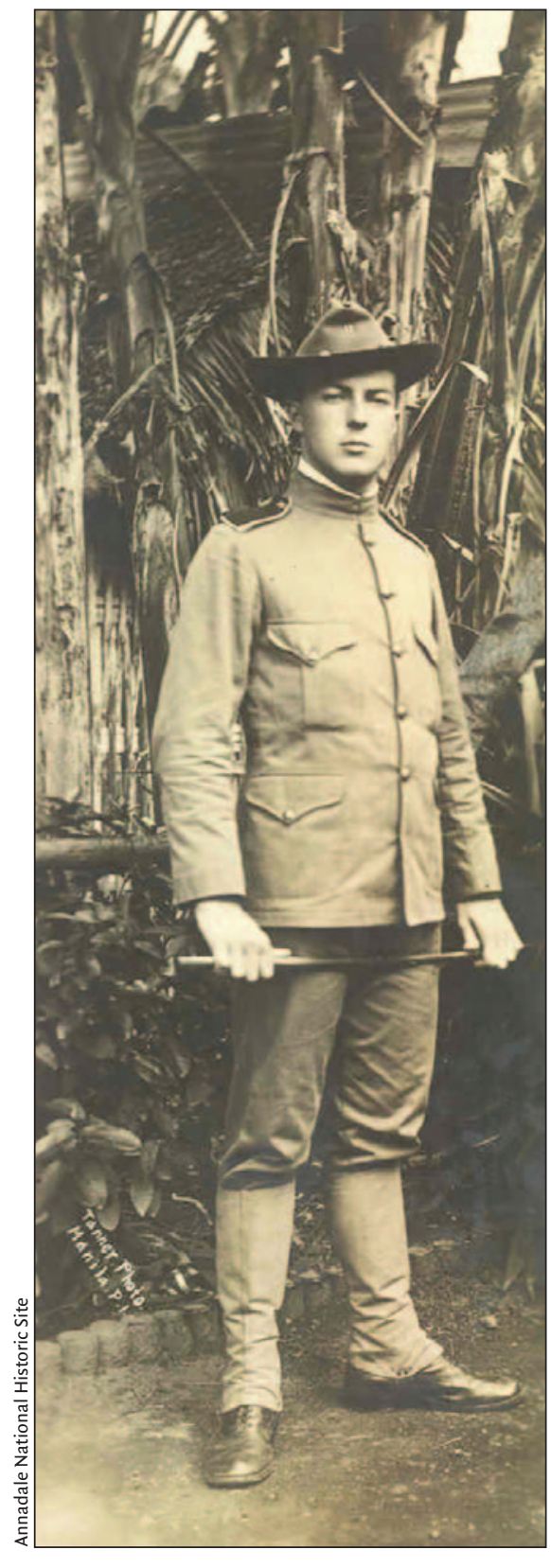

Harrison served in 8 armies around the world, including the US Army Engineers in Luzon Island, Philippines, in 1901 or 1902. 


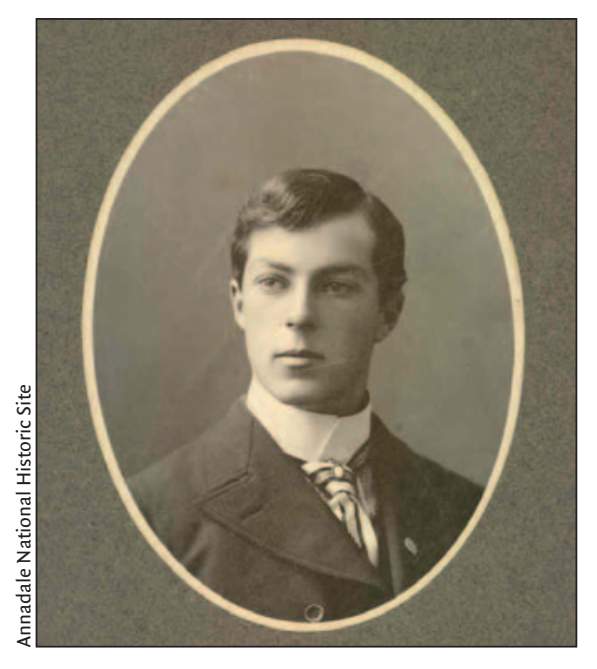

Harrison graduated from the University of Toronto Medical School in 1907.

cording to the late Ted Tillson, a distant relative). Sentenced to die before a firing squad, Harrison gained a reprieve when the enemy general became ill. Harrison kept the man in a state of near wellness until he could effect his own escape.

In 1917 , Harrison joined the Canadian Army, abandoned Eva, and served in France as a physician to the Chinese Labour Corps, which carried stretchers, dug trenches and delivered ammunition. Harrison learned their language and customs, while treating such ailments as catarrh, emphysema and trachoma. He deplored the way they were treated, including the shearing of pigtails, the forced wearing of riveted identification bracelets and racial taunts. Michael Summerskill, in China on the Western Front, mentions Harrison's reducing "sick parade" numbers from over 30 to less than 5 during the winter of $1917-1918$, gaining him great "face" among the Chinese.

In I920, Harrison journeyed to Syria, the Sudan and Mesopotamia, married Malta-born Filomena Abela in Alexandria, ran a radiograph facility in Lydda and a hospital in Constantinople, eloped with a Turkish officer's wife, but was captured, court-martialled and deported to Canada. He jumped ship in Morocco and made his way to Ireland in 1922, where he masqueraded as a Catholic (though born Methodist) and joined the Free State Army.

He was soon unmasked, however, and left to tend to Welsh coal miners suffering from silicosis. He married Ol- wen Bowen in 1923. During the I920s and I93os, he practised in a dozen Caribbean and Latin American locales.

Harrison then felt the call of China, and served as physician to a guerrilla army fighting the Japanese, his activities paralleling those of Bethune, who died while on campaign in 1939 with another unit. Harrison later practised in Shanghai.

During World War II, he served as Ship's Doctor aboard the VSIS (Victualling Store Issue Ship) Demodocus, ferrying food and medical supplies to Allied forces around the Indian Ocean. He once set the broken forelegs of the ship's mascot after the poor pooch tumbled down a gangway.

After the war, he falsified his records by subtracting 7 years from his birth date so that he could qualify for United Nations Relief and Reconstruction Administration Service. He and his colleagues brought food, medicine, and other much-needed supplies - as well as moral and spiritual comfort - to thousands of starving, beleaguered villagers whose lives and land had been ravaged repeatedly by Japanese troops and, to some degree, homegrown warlord armies.

Many of the latter were the fiercely anti-Communist Kuomintang under Chiang Kai-Shek, who sacrificed lives mercilessly to halt what was perceived as the spreading scourge of Communism.

Although Harrison was then in his sixties, he worked tirelessly to mobilize trucks and trains. On one occasion, he put on an American officer's uniform to double-talk a Kuomintang officer out of searching a barge in which Harrison was hiding some go student volunteers. Had they been discovered, they would have been shot immediately as communists.

Harrison's first truck convoy was strafed by Kuomintang aircraft, despite its clear markings, but it got through. A second convoy survived because overcast skies grounded aerial predators.

Harrison typed plaintive reports about the distressed country folk whom he encountered, including a village of women blinded by syphilis, a by product of Japan's nebulous "Southeast Asian Co-Prosperity Sphere.” But his service to China was short. In January I947, the Kuomintang sidetracked his train and appropriated his locomotive; brigands stole his greatcoat and bedding. He and his men ate donkey meat, begged villagers for eggs, and brewed "coffee" made from filtered, boiled ditch-water. On the night of January Io, the doctor died in his sleep from exhaustion and malnutrition. Foul play was ruled out in favour of death from "natural causes."

Despite a New York Times obituary, memorial articles throughout the world, even a letter in $\mathrm{I} 988$ from then-Canadian prime minister Brian Mulroney to the Chinese ambassador on the centenary of Harrison's birth, he remains relatively unknown in Canada.

In China, however, his fame continues. There is a statue of Harrison in Shanghai, and the Anglican compound where he is buried in Kaifeng now houses the Dr. Tillson Harrison Memorial School, while the Harrison Hospital in Hengshui treats some 800 outpatients every day. There are loving films and histories of Harrison, and millions of Chinese youngsters have pictureand colouring books dedicated to the gallant "Grandpa Harrison."

Decades later, George Lucas and Stephen Spielberg contacted Harrison's only child, Rosalind, who told her father's life story in a series of interviews. She claims these stories inspired the filmmakers to develop the Indiana Jones saga. They cast the celluloid hero as an

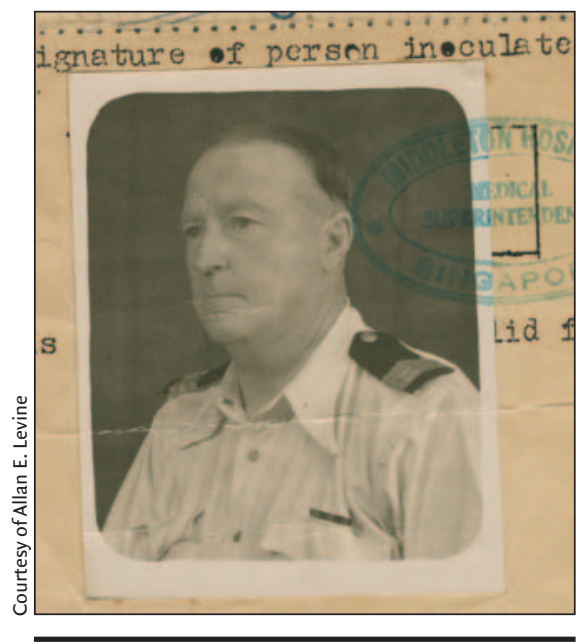

This photo, from Harrison's certificate of inoculation against cholera, was taken in Singapore in 1946 when he was $\sigma_{5}$ years old, although the certificate states he is 50 . 
archeologist, perhaps because medicine was too tame for Hollywood. Or perhaps they wanted to disguise the identity of Indy's inspiration. If Indiana Jones is indeed the cinematic version of Harrison, then the 3 films thus far fail to recount his true life adventures. Perhaps the fourth film, due for release in May 2008 , will do his story justice.

Harrison's medical school graduation portrait was accompanied by this quotation from Shakespeare's Macbeth, "I dare do all that may become a man!" If we do get the long-awaited silverscreen version of his life, we may be able to appreciate, with warts and all, the true measure of Dr. Tillson Lever Harrison, Chinese hero extraordinaire.

\section{Allan E. Levine MLS \\ Ottawa, Ont.}

Allan E. Levine is a librarian, researcher and military historian working on a definitive biography of Dr. Harrison.

\section{Militi Succurrimus}

As Remembrance Day approaches, readers may be interested to know the origins of the Canadian Forces Medical Services' (CFMS) motto. Dr. Michael Warrington LCol (Hon. Ret'd) recounts the following.

"In 1976 , while serving as medical officer in the British Columbia Regiment (Duke of Connaught's Own), I was asked by the area surgeon, LCol Anthony Grasset, if I had any ideas for a motto for the CFMS. We had both studied medicine at Middlesex Hospital (est. 1745) in London, UK. The hospital's motto Miseris Succerrere Disco (I am learning to succour the distressed) was inspired by a quotation from the Aeneid by Virgil (70I9 BC) at the part where Queen Dido says to Aeneas when he was cast upon her shores: 'Non ignara mali, miseris succurrere disco' (Knowing something of mis$\infty$ fortune myself, I am learning to succour the distressed). I suggested that we adapt this motto. On Aug. Io, I988, the CFMS adopted Militi Succurrimus (We succour the soldier) as its motto." - Submitted by Dr. Michael Warrington LCol (Hon. Ret'd), Tsawwassen, BC

\section{Film and other media}

\section{Filming at the front lines of health}

I t started out as a 6-week program, but turned into a life-changing experience for the handful of sometime-homeless young mothers who have learned to film, take photos, audiotape and maintain Internet blogs — among other accomplishments.

"It just gives you so much confidence," says 23-year-old Adrienne, one of the 5 mothers who first documented ture some key aspects of the lives of others.

Katerina Cizek, filmmaker-inresidence at St. Michael's Hospital (see page 1240), trained the young mothers to use digital cameras and keep photoblogs. Their work led to an image and text exhibit, I WAS HERE, that provided a window into their own lives and was launched at Toronto City Hall last January. In an artists' statement, the women said they hoped the exhibit would "take the judgemental edge off and change t people's perceptions of us."

Next, they organized a "speak out" and invited other young parents to talk about the problems they face and brainstorm about solutions. That led to an astonishingly comprehensive docutheir own lives and then turned to cap- ment, WE ARE HERE: A Declaration by Young Parents, that laid out changes the group wanted to see in areas such as social assistance, childcare, housing, healthcare and education. The declaration has been endorsed by the Society of Obstetricians and Gynaecologists of Canada and has been circulated among social assistance workers.

"As young mothers, we find it hard to speak out, with doctors, social workers and people on the street who stare at us" as if they think we are too young, says Jess. "So there is personal satisfaction about raising the issues, about 'having said that' and letting the public know how hard it is," the 20year-old explained.

Armed with new skills and confidence, the young women were hired to conduct and audiotape interviews with homeless people on the streets of Toronto. The result, Street Health Stories, is a photo and sound exhibit that gives voice to the homeless that is now being mounted in various locations around Toronto. The interviewees tell stories about their lives. Nancy, one of those interviewed, observes: "If people were housed, they could take care of

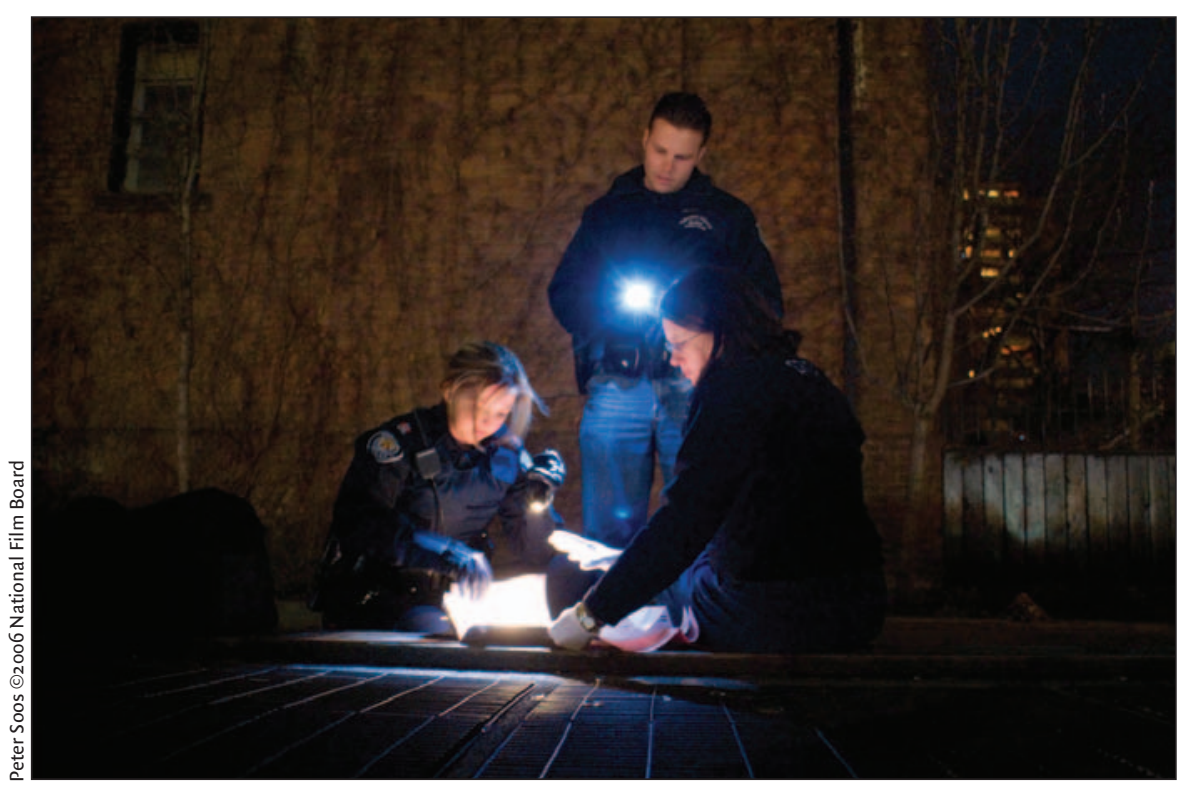

Cizek's vérité film, The Interventionist, follows a mental health nurse and a police officer as they respond to 911 calls involving "emotionally disturbed persons." 